\title{
JÄLKIKEYNESIÄ KELTANOKILLE
}

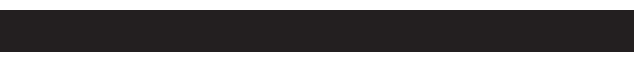

Antti Alaja \& Esa Suominen: Taloutta työväelle. Markkinaliberalismin myyttejä murtamassa. Helsinki: Into 2013.

Kysymys uudenlaisen talouspolitiikan mahdollisuudesta on pyörinyt monien mielissä vuonna 2008 alkaneen rahoitus- ja talouskriisin jälkeen. Viime aikoina erityisesti Keynesin teoriasta on etsitty vastauksia kysymyksiin, joista yleisimmät ovat varmastikin tarve markkinoiden poliittiseen ohjaukseen sekä uusklassisen talousparadigman epäuskottaviksi osoittautuneiden perusoletusten purkaminen. Toistaiseksi keynesiläisyyden uudet versiot eivät ole kyenneet vakavasti haastamaan uusklassista mallia, joka pitää otteensa toistuvista kriiseistä ja ilmiselvistä taloudellisista virhearvioista huolimatta.

Keynesiläisyyden uusi tuleminen ei lupaa kapitalismin tai markkinatalouden ylittämistä. Tämä ei ole koskaan ollut Keynesin tai hänen seuraajiensa tavoite. Keynesin oppeja ovatkin herätelleet ja uusia analyyseja tarjonneet erityisesti sosiaalidemokraatit. Taloutta työväelle -teos on hyvä esimerkki tästä tendenssistä. Antti Alaja toimii projektitutkijana Kalevi Sorsa -säätiössä ja Esa Suominen puolestaan opetusministeri Krista Kiurun erityisavustajana. Molemmilla kirjoittajilla on jo pitkä tausta sosialidemokraattisessa puolueessa. Toistaiseksi he eivät edusta puolueen virallista talouspoliittista linjaa, mutta tulevaisuudessa tilanne voi muuttua. Asioita ulkopuolelta seuraavalle yhteiskuntatieteilijälle on tullut sellainen vaikutelma, että demareiden johdolla ei ole ollut viimeisen vuosikymmenen aikana selkeää talouspoliittista näkemystä varsinkaan sellaista, jonka perustalle voitaisiin rakentaa pitkäjänteistä, omaehtoista ja ennen kaikkea oikeistolaista uusklassista vyönkiristyspolitiikkaa kyseenalaistavaa talousajattelua.
Alajan ja Suomisen teoksen erityisenä ansiona on joskus monimutkaisten mutta ennen kaikkea monipolvisten Keynesin talousteoriaan perustuvien taloustieteellisten ja talouspoliittisten mallien kansantajuistava ja yleissivistävä läpikäynti. Teos on kirjoitettu selkeästi ja jäsennetty tasapainoisesti kolmeen pääosaan. Kirjan alaotsikon mukaisesti siinä puidaan paljon myös keynesiläisyyden suhdetta uusklassiseen teoriaan. Teos on myös hyvällä tavalla avoimesti poliittinen. Etenkin kirjan loppupuolella kirjoittajat tekevät konkreettisia ehdotuksia uuden sosiaalidemokraattisen talouspolitiikan puolesta. Käsittelen seuraavaksi lyhyesti kirjan pääteemat ja pohdin lopuksi mahdollisen keynesiläisen sosiaalidemokraattisen talouspolitiikan mahdollisia heikkoja kohtia.

\section{KEYNESILÄISYYDEN MONET POLUT}

Kirjan ensimmäiset noin 50 sivua keskittyvät esittelemään Keynesiä ja keynesiläisyyden tarinaa taloushistoriassa. Kirjoittajat tiivistävät vaiheet muutamiin keskeisiin aikakausiin, joista tärkein ja tunnetuin on toisen maailmansodan jälkeen rakennettu Bretton Woods -talousjärjestelmä (1944-1971). Bretton Woods -järjestelmä perustui kansainvälisten pääomaliikkeitten säätelyyn sekä valuuttakurssien muuttamiseen kiinteäksi, dollariin perustuvaksi järjestelmäksi. Dollari puolestaan sidottiin kultakantaan. Samalla monet valtiot (mm. Yhdysvallat, Iso-Britannia ja Ruotsi) alkoivat soveltaa uusklassista keynesiläistä makrotalouspolitiikkaa, jonka tähtäimessä oli täystyöllisyys ja suhdanteiden vakauttaminen raha- ja finanssipolitiikalla. Myös Suomessa seurattiin Keynesin jalanjälkiä, sillä Kekko- 
sen talouspolitiikka sai siitä paljon vaikutteita. Vuonna 1951 Ahti Karjalainen ja Pentti Kivinen suomensivat Keynesin Yleisen teorian.

Tämä uusklassisen keynesiläisyyden kulta-aika päättyi vuonna 1971, jolloin Bretton Woods -järjestelmä purettiin osittain sen sisäisten ristiriitaisuuksien vuoksi, sillä makroja mikrotalous eivät olleet siinä tasapainossa. Makrotalous perustui keynesiläisiin oppeihin, kun taas mikrotaloudessa noudatettiin uusklassisia periaatteita. 1970-luvun alusta lähtien keynesiläisyyden haastajaksi ja lopulta selättäjäksi nousi uusklassinen taloustiede, jota kehiteltiin Chicagon yliopiston taloustieteen laitoksella jo 1950-luvulta lähtien. Sen tärkeimpiä teoreetikkoja olivat Milton Friedman, Robert Lucas ja Robert Barro. Uusklassisen koulukunnan kehittämä makrotalousteoreettinen monetaristinen oppi keskittyi rahan määrän vakaaseen kasvuun taloudessa. Rahan määrän tasaisen kasvun uskottiin luovan "luonnollista" ja vakaata kasvua. Monetaristit uskoivat markkinoiden itseään tasapainottavaan voimaan, minkä vuoksi keynesiläinen ajatus aktiivisesta finanssi- ja suhdannepolitiikasta joutui huonoon valoon. Voimakas stagflaation eli lamatalouden olosuhteissa ilmaantuva korkean inflaation ja työttömyyden kausi 1970-luvulla osoitti, että uusklassinen keynesiläisyys ei toiminut. Myöhemmin monetaristisesta opista pääasiassa luovuttiin uusklassisen teorian piirissä.

Uusklassinen keynesiläisyys siis epäonnistui, mutta Keynesin malleja ei täysin hylätty. 1970-luvun alusta lähtien alkoi muodostua niin kutsuttu jälkikeynesiläinen talousteoria. Jälkikeynesiläiset olivat radikaalimpia kuin heti sodan jälkeen Bretton Woodsia rakentaneet uusklassiset keynesiläiset ja korostivat, että Keynesin teoriaa ei tulisi vesittää vaan päinvastoin toteuttaa uskollisemmin. Jälkikeynesiläiset poikkeavat myös 1980-luvulta lähtien paljon esillä olleista niin kutsutuista uuskeynesiläisistä talousteoreetikoista, jotka ovat lähellä uusklassista teoriaa. Uuskeynesiläiset teoreetikot olivat keskeisiä toimijoita rakennettaessa niin sanottua uutta uusklassista synteesiä tai uutta makrotaloudellista konsensusta, jota suurin osa nykyisestä valtavirran taloustieteestä noudattaa. Siksi uuskeynesiläistä teoriaa pidetään toisena vallitsevista valtavirtaisista talousteorioista. Tämän koulukunnan tunnetuimmat teoreetikot ovat Joseph Stiglitz ja Paul Krugman. Kaikki jälkikeynesiläiset eivät kuitenkaan allekirjoita uuskeynesiläisten oppeja, ja jotkut eivät edes pidä uuskeynesiläisiä keynesiläisinä.

Toisin kuin uuskeynesiläisyydestä, jälkikeynesiläisestä talousajattelusta on muodostunut eräänlainen laajahko taloustieteen toisinajattelijoiden ryhmä, joka ei ole kuitenkaan vielä onnistunut vakiinnuttamaan asemaansa yliopistoissa, saati niissä elimissä, joissa päätetään valtioiden talouspolitiikasta. Joka tapauksessa jälkikeynesiläiset teoreetikot ovat pyrkineet kehittämään eteenpäin tuotannon rahateoriaa eli ajatusta epävarmaan talouteen varmuutta ja vakautta - ja näin myös investointeja - tuovasta isosta pankista, siis käytännössä itsenäiseen rahoitukseen kykenevästä keskuspankista. Yleisesti jälkikeynesiläiset korostavat entistä uskollisempaa Keynesin Yleisen teorian -tulkintaa ja vastustavat uusklassisen teorian perusaksioomia. Koulukunnan suuria nimiä ovat Michal Kaleck (jota kaikki tosin eivät pidä jälkikeynesiläisenä), Sidney Wintraub, Paul Davidson, John Kenneth Galbraith ja Joan Robinson. Alajan ja Suomisen kirjassa ääneen päästetään nimenomaan jälkikeynesiläinen talousteoria, jolle ei heidän mukaansa ole annettu julkisessa tai taloustieteellisessä keskustelussa tarpeeksi tilaa.

\section{TALOUS TOIMII LUONNOLLISESTI}

- TAI SITTEN EI

Alun teoriahistoriallisten käsittelyiden jälkeen kirja pääsee varsinaiseen sisältöönsä ensimmäisen uusklassisen myytin purkamisen kautta. Yksi uusklassisen ajattelun perusparadigma on usko markkinoiden kykyyn korjata itseään "luonnollisesti”. Tästä syystä markki- 
noiden toimintaan ei saisi puuttua, eikä niitä saisi "vääristää" valtioiden toimesta. Tietyt tahot ovat menneet jopa väittämään, että syyt mittaviin talousromahduksiin ja -kriiseihin on sälytettävä valtioiden niskoille. Tämän näkemyksen mukaan ilman valtioiden harrastamaa väärää talouspolitiikkaa markkinat olisivat kyllä korjanneet tilanteen itse.

Uusklassisen teorian mukaan markkinoiden toimijat ovat aina rationaalisia, minkä vuoksi edes rahoitusmarkkinoita ei tulisi kontrolloida. Tähän ajatukseen perustuvaa politiikkaa harjoitettiinkin käytännössä ennen vuoden 2008 finanssikriisiä. Esimerkiksi Yhdysvaltain keskuspankin entinen johtaja Alan Greenspan antoi ymmärtää, että rahoitusmarkkinat korjaavat itsenäisesti omat virheensä markkinalogiikan mukaisesti ja hakeutuvat automaattisesti tasapainotilaan. Näin ei kuitenkaan tapahtunut, ja seuraukset ovat tunnetut. Siksi rahoitusmarkkinoiden toiminnasta tarvitaan todenmukaisempi kuva, ja tällaista kuvausta kirjoittajat etsivät Hyman P. Minskyn (jonka kuuluminen jälkikeynesiläiseen koulukuntaan on myös asetettu kyseenalaiseksi) rahoitusmarkkinoiden epävakaisuushypoteesista.

Alaja ja Suominen esittävät, että kuten Keynes aikoinaan myös Minsky näkee tulevaisuuden perustavalla tavalla epävarmana. Kapitalismi ja sitä myöten myös rahoitusmarkkinat ovat epävakaita - ne siis heilahtelevat vakaudesta epävakauteen ja hyvistä ajoista huonoihin. Minskyn mukaan rahoitusmarkkinat ovat kapitalismin lähde ja samalla sen syklisyyden syy. Noususuhdanteet luovat epävakautta talousjärjestelmään, eikä kapitalistinen markkinamekanismi voi siksi taata jatkuvaa tasapainotilaa, jossa vallitsisi hintavakaus ja täystyöllisyys. Talouspolitiikan tehtävänä on laskukausien vaikutusten lieventäminen ja näin ollen myös köyhyyden vähentäminen. Tämä voi tapahtua ainoastaan muuttamalla nousukausia ja rahoitusta maltillisemmiksi.

Minskylle on tärkeää huomioida taloudellisen toiminnan todellinen historiallinen konteksti. Uusklassinen taloustiede toimii "loogi- sessa ajassa" olettaen, että olosuhteet ja perusasetelmat ovat aina samat. Minsky puolestaan korostaa historiallisen ajan merkitystä analyysille. Minskyn mukaan raha syntyy talouteen endogeenisesti eli kysynnän kautta, pankkien luomana. Siksi investoinnit muuttavat koko järjestelmää (investoinnit lisäävät rahan tarvetta), eikä niiden suhde esimerkiksi korkotasoon ole vakio. Suuret kulutusodotukset luovat suuria investointioletuksia, minkä seurauksena yritykset ottavat lainaa ja luovat näin lisää rahaa.

Mitä enemmän yritykset ja kotitaloudet tavoittelevat voittoa, sitä enemmän tulee tarjolle erilaisia rahoitusinstrumentteja. Minsky ei niinkään näe reaalitalouteen perustuvaa hedge- eli vipurahoitusta ongelmallisena, vaan hän varoittaa spekulatiivisesta rahoituksesta ja erityisesti Ponzi- eli pyramidirahoituksesta. Kaksi viimeksi mainittua rahoitusinstrumenttia ovat erityisen alttiita muutoksille rahoitus- ja varallisuusmarkkinoilla, sillä korkomenojen kasvu suistaa ne välittömästi maksuongelmiin.

Epävakaisuushypoteesi perustuu paljolti oletuksiin ihmisen psykologiasta (Keynesin animal spirits): ihmiset eivät ole rationaalisia vaan unohtavat vähitellen kokemansa tappiot ja konkurssit. Tämä väistämättä johtaa kasvavaan investointi-intoon ja talouden ylikuumenemiseen. Toisin sanottuna mitä paremmin taloudessa menee ja mitä vakaampia voitot ovat, sitä helpommin talousjärjestelmä ajautuu ottamaan suuria riskejä ja sitä kautta kriisiytyy. Siksi taloudellisten toimijoiden olisi aina muistettava talouden epävakaisuus ja pitäydyttävä maltillisissa investoinneissa ja riskeissä.

Kirjassaan Alaja ja Suominen korostavat, kuinka Minsky ehdottaa markkinoiden epävakaisuuden vastapainoksi "isoa" eli taloudellisesti vaikutusvaltaista valtiota. Minsky ei kuitenkaan kannata sosialismia, siis valtion päätöksiä siitä, mille aloille sijoitetaan ja millaisia hyödykkeitä tuotetaan. Sen sijaan valtion tulee valvoa talouden kokonaiskehitystä ja pääomanmuodostusta ja tasapainottaa talouden suhdanneheittelyä välineinään niin sanotut automaattiset vakauttajat, kuten työttömyysturva ja muut sosiaaliturvajär- 
jestelmät. Ne toimivat aina vastasyklisesti, siis piristäen taloutta ja kulutusvoimaa silloin, kun talous ajautuu lamaan. Ne ovat toimivia myös siksi, että valtion ei tarvitse ryhtyä erityisiin elvytystoimiin. Laman aikana muodostuneet valtion alijäämät auttavat (julkisen sektorin velkaantumisen kautta) yrityksiä selviämään maksuistaan ja tätä kautta investoimaan. Minskyn teoriassa kansalaisten ostokyvyn ylläpitäminen nähdään siis tärkeämmäksi kuin julkisen sektorin velkaantumisen estäminen, koska valtio kykenee lyhentämään velkojaan taas nousukauden aikana. Myös Alaja ja Suominen suosittelevat tämän suuntaista talouspolitiikkaa.

Automaattiset vakauttajat ehkäisevät myös varallisuusmarkkinoiden romahtamista. Esimerkiksi työttömyysturva mahdollistaa sen, että työttömäksi joutuva ei joudu myymään, ainakaan välittömästi, asuntoaan. Näin asuntojen arvot säilyvät, eikä kaoottisia varallisuuden häviämiseen johtavia syklejä pääse muodostumaan. Luonnollisesti tällainen järjestelmä on myös sosiaalisesti oikeudenmukainen ja ehkäisee pääomien kohtuutonta kasautumista ja omaisuuden rohmuamista laman aikana. Kuten teoksen kirjoittajat huomattavat, voitaisiin jopa väittää, että juuri automaattiset vakauttajat estävät kapitalismia tuhoamasta itse itseään.

Minskyä seuraten kirjoittajat korostavat, että rahoitusjärjestelmän kriisissä vain vaikutusvaltainen keskuspankki voi toimia viimekätisenä lainaajana ja turvata markkinoiden rahoituksen. Mielestäni keskuspankkien toiminnassa "pelastavina enkeleinä" on kuitenkin omat ongelmansa, sillä se rohkaisee riskisijoituksia ja riskipankkeja jatkamaan toimintaa riskialttiilla tavalla. Kuten Pekka Piironen on teoksessaan Epävarmuuden talous esittänyt, nykyisessä taloudessa kaikki riskit takaa viimekädessä "kollektiivinen vakuus" eli siis työtätekevät kansalaiset ja veronmaksajat. Tälle systeemiselle vialle tulisi tehdä Minskyn mukaan jotain, vaikka hänen mukaansa pankit onkin aina pakko pelastaa ongelmista, jotta koko järjestelmä ei kaadu.
TYÖTÄ KAIKILLE - MUTTA MITEN?

Kirjan toinen osa keskittyy purkamaan myyttiä, jonka mukaan joustavat työmarkkinat tuovat kaikille töitä. Uusklassisten näkemysten mukaan työttömyys on aina loppujen lopuksi vapaaehtoista. Ihmiset joutuvat työttömiksi pääasiassa siksi, että he eivät ole valmiita ottamaan (mitä tahansa) työtä vastaan tarjotulla palkalla: työtä on siis aina tarjolla, jos vain hinnasta sovitaan. Tuotanto työllistää kaikki työvoimaresurssit automaattisesti, jos se vain on kannattavaa.

Kirjoittajat esittävät, että jälkikeynesiläisyys perustuu tätä vastoin Keynesin ajatukseen, jonka mukaan työmarkkinoilla esiintyy aina myös vastentahtoista työttömyyttä: ihmiset olisivat halukkaita tekemään työtä, mutta sitä ei vain yksinkertaisesti ole tarjolla. Työn rajallinen tarjonta johtuu puolestaan kokonaiskysynnän vähäisyydestä, eli tuotannossa tuotettaville tuotteille ei ole riittävää kysyntää. Kysynnän vähyys voi johtua eri syistä, mutta tärkein on se, että ihmisillä ei ole varaa kuluttaa. Näin käy erityisesti laman aikana, jolloin ihmiset alkavat helposti säästämään. Lamassa valtion olisikin pidettävä huolta kokonaiskysynnästä.

Uusklassisessa työllisyyspolitiikassa lähdetään aina liikkeelle työn tarjonnan lisäämisestä, jolla pyritään saamaan "luonnollinen" palkkataso niin alhaiseksi, että kaikki työkykyiset ihmiset työllistyvät. Palkkatason ollessa riittävän matala investoiminen on kannattavaa. Työn tarjontaa painottava työllisyyspolitiikka näkee lähtökohtaisesti kaikki työn tarjontaan vaikuttavat järjestelmät rajoittavina ja haitallisina. Liian korkeat palkat, työttömyysturva ja irtisanomissuoja ovat kaikki työn "luonnollista" tarjontaa rajoittavia tekijöitä. Sama koskee tietysti myös esimerkiksi sosiaaliturvaa. Ilman työttömyys- ja sosiaaliturvaa ihmiset olisivatkin "vapaita" työllistymään sillä palkalla, jonka työantaja heille tarjoaisi. Ei ihme, jos joidenkin mielestä liberaali malli kuulostaa enemmän pakolta kuin vapaudelta. Jälkikeynesiläisten 
mielestä noin 210 vuotta vanha Sayn laki (tarjonta synnyttää oman kysyntänsä) on kuitenkin aikansa elänyt eikä pidä paikkaansa.

Liberaalissa talouspolitiikassa ajatellaan Adam Smithin kuuluisan idean mukaisesti, että taloudessa eräänlainen näkymätön käsi ohjaa yksilöiden toiminnan parhaaseen kokonaisuuteen. Keynesiläiset taloustieteilijät eivät usko tähän malliin. Heidän mukaansa on tärkeää harjoittaa talous- ja finanssipolitiikkaa nimenomaan täystyöllisyyttä ja hintavakautta tavoitellen. Euroopassa "rakenteellinen" työttömyys on ollut arkipäivää viimeistään 1980luvulta lähtien. Tilannetta on yritetty ratkaista pääasiassa syyttämällä hyvinvointivaltioita joustamattomista työmarkkinoista. Lääkkeeksi on esitetty työvoiman "suojelun" purkamista ja”joustojen" lisäämistä.

Euroopassa työmarkkinoita on pyritty joustavoittamaan Tanskan mallilla eli niin sanotulla flexicurity-järjestelmällä, jossa ihmisten liikkuvuutta työmarkkinoilla rohkaistaan korkealla tilapäisellä työttömyys- ja sosiaaliturvalla. Toinen malli on ollut niin sanottu Saksan malli eli 2000-luvun alussa Gerhard Schröderin johtaman punavihreän hallituksen ajamat Hartz-reformit, jotka leikkasivat työttömyysturvaa ja heikensivät työsuhdeturvaa. Tämän seurauksena Saksan työmarkkinoilla onkin vallinnut koko 2000-luvun poikkeuksellisen korkea työllisyysaste ja työttömyys on pysynyt matalana vielä vuoden 2008 kriisin jälkeenkin. Tarina ei kuitenkaan ole aivan näin ruusuinen, sillä Saksan tilastokeskuksen mukaan lähes kaikki uudet työpaikat syntyvät käytännössä prekaareihin töihin. Prekaarien töiden määrä onkin lisääntynyt yli 2 miljoonalla työpaikalla viimeisen 10 vuoden aikana. Pätkätyöläisten määrä on nykyisin noin kolmasosa Saksan työläisten kokonaismäärästä. Prekariaatin lisääntyminen on tarkoittanut työtätekevien köyhien määrän nopeaa kasvua. Saksan malli tuottaakin aktiivisesti matalapalkka-aloja ja samalla myös työtä tekevien köyhien luokan.

Vaikka kirjassa ei puhutakaan prekarisaatiosta, huomauttavat kirjoittajat siitä, kuinka yhteiskunnallisessa keskustelussa työtätekevät köyhät, työttömät tai "syrjäytyneet" eivät useinkaan näyttäydy talouspolitiikan rakenteellisten toimenpiteiden tuotteina, vaan syyt yksilöiden työttömyyteen tai köyhyyteen varsin perinteiseen tapaan löytyvät heistä itsestään. Kuten jo Karl Marx korosti, yksi kapitalismin vahvimpia perustamismyyttejä on ajatus siitä, että köyhät ovat itse aiheuttaneet kurjan tilansa. Nykyisin tätä samaa myyttiä toistetaan virallisen talouspolitiikan tasolla, ja työttömyysongelma pyritään ratkaisemaan yhä enemmän työläisten työkyvystä huolehtimisen kautta. Työkykypolitiikkaa vastaan jälkikeynesiläinen ajattelu korostaa, että työttömyys on aina kansantalouden tehottomuutta ja resurssien hukkaamista. Työttömyyden syynä on talouspolitiikan epäonnistuminen, ei yksilö.

Kuinka jälkikeynesiläiset sitten ratkaisisivat työllisyyspolitiikan kysymykset? Ensimmäisenä lähtökohtana kirjassa esitetään täystyöllisyyden tavoittelu. Täystyöllisyys on puolestaan todennäköisemmin saavutettavissa, jos kokonaiskysyntä laajentuu jatkuvasti ja riittävästi. Valtion rooli, tai kenties EU:n rooli, on toimia siksi "suurena kuluttajana”, joka kykenee palauttamaan markkinoiden ja investoijien luottamuksen talousalueeseen. Investoijat kun eivät voi tehdä sijoituksia vain nousukausien tuottojen perustalle, vaan heidän tulee nähdä menekkimahdollisuudet myös laman aikana. Siksi valtioiden tulee elvyttää runsaasti, mikä johtaa yleensä julkisen talouden alijäämään. Tämän kuitenkin katsotaan pitävän yllä investointihalukkuutta ja kulutuspotentiaalia, minkä vuoksi se nähdään kannattavana.

Työllisyyspolitiikan Keynes-ratkaisu on siis aktiivinen finanssipolitiikka, joka tähtää täystyöllisyyteen, mutta ei sulje pois yksityisiä investointeja. Täystyöllisyyden tilassa julkisen sektorin menot laskevat minimiin, minkä vuoksi otettua velkaa voidaan maksaa pois ja julkisen sektorin kulutusta voidaan supistaa. Näillä toimilla voitaisiin kirjan kirjoittajien mukaan tavoitella uudenlaista eurooppalaista New Dealia. Sen tavoitteena olisi tarjota kai- 
kille halukkaille työtä. Ratkaisuna ei ole työvoiman lisätarjonta tai julkisen sektorin leikkaukset, jotka uhkaavat köyhdyttää viimeisetkin kuluttajat. Sen sijaan avuksi kaivataan isoa pankkia, Euroopan keskuspankkia, joka voisi toimia viimekätisenä luotottajana ja rahoittajana Japanin ja Yhdysvaltojen keskuspankkien tapaan. Tällainen iso pankki toisi väistämättä vakautta työmarkkinoille. Iso pankki voisi johtaa Euroopan myös pysyvämmälle kasvuuralle. Kokonaisinvestointiasteen nostaminen toisi rahavirtoja talouteen ja samalla kasvattaisi Euroopan tuotantopotentiaalia.

\section{ERIARVOISUUS VAI TASAINEN TULONJAKO?}

Kirjan kolmannessa osassa pohditaan myyttiä, jonka mukaan riittämätön kulutuskysyntä ei voi rajoittaa talouskasvua. Kirjoittajat tarkastelevat siis viime vuosikymmeninä myös länsimaisissa hyvinvointivaltiossa kiihtynyttä sosiaalista ja erityisesti taloudellista eriarvoisuutta. 1980-luvulta lähtien vaikuttanut "rakenteellinen työttömyys" yhdistettynä uusklassiseen ja uusliberaaliin talouspolitiikkaan on pakottanut valtioita muuttamaan tulontasausjärjestelmiään: sosiaaliturva ja verotus tuottavat nykyisin enemmän eriarvoisuutta kuin aiemmin, eli tulot eivät jakaudu tasaisesti. Lisäksi palkkakehitys on irronnut tuottavuudesta. Vaikka työn tuottavuus on noussut huimaa vauhtia kymmeniä vuosia, eivät palkat ole kehittyneet samaa tahtia. Näyttää siltä, että Marxin perusnäkemys työn koneellisesta tehostamisesta pitää tässä yhteydessä paikkansa. Työ ja tuotanto tehostuvat, mutta lisäarvoa ei kerää työntekijä vaan yritysten omistajat. Näitä kaikkia teemoja käsitellään kirjan kolmannessa osassa tasaisen tulonjaon kysymyksen kautta.

Tasaisella tulonjaolla on tunnettuja moraalisia, sosiaalisia ja kenties myös poliittisia hyötyjä, mutta tässä tarkastelussa ovat erityisesti taloudelliset hyödyt. Monet poliitikot vaativat suurempia tuloeroja, ja jotkut AY-liikkeen johtajatkin ovat liittyneet vaatimukseen. Esimer- kiksi Akavan Sture Fjäder ilmoitti avoimesti, että Suomeen kaivataan lisää tuloeroja. Kaikki nämä tapaukset kertovat arvomaailmasta, mutta myös siitä taloustieteellisestä paradigmasta, johon monet johtoportaan edustajat tukeutuvat. Johtoportaan moraalista paheksuntaa on esiintynyt monilla tahoilla, minkä vuoksi Alajan ja Suomisen esittämät taloudelliset perusteet tasaisen tulonjaon puolesta ovat tervetulleita.

Kirjassa Alaja ja Suominen pyrkivät siksi osoittamaan Michal Kaleckin teorioiden avulla, että tasapuolinen tulonjako edistää taloudellista toimintaa, ei hidasta sitä. Tämä malli voi johtaa palkkavetoiseen talouspolitiikkaan, joka kirjoittajien mukaan toimisi uusklassisen velka- ja vientivetoisen talouspolitiikan haastajana. Perusajatuksena on, että tasaisempien palkkatulojen kautta voidaan rakentaa kasvava talous, joka olisi huomattavasti tasapainoisempi ja oikeudenmukaisempi kuin velka- ja vientivetoinen kasvutalous. Tällaisen talousjärjestelmän ensimmäisenä tavoitteena eivät ole suuret voitot vaan mahdollisimman suurta kokonaiskysyntää ylläpitävät tasaisen suuret palkkatulot ja täystyöllisyys.

Palkkavetoisiksi talouksiksi voidaankin itse asiassa luokitella suurin osa suurista länsimaisista talouksista, kuten Yhdysvallat tai EU. Toisin sanoen, mitä suurempi talousalue ja mitä suuremmat sisämarkkinat, sitä todennäköisemmin ne toimivat palkkavetoisella logiikalla. Kuten kirjoittajat korostavat, tämä asettaa tietenkin haasteita suomalaisen talouspolitiikan pohtimiseen, sillä Suomi on pieni, viennistä riippuvainen talous. Palkkavetoisen talouden opit eivät siis suoraan sovi suomalaiseen talousmalliin, vaikkakin on huomattava, että vientiriippuvuudesta huolimatta kaikki Pohjoismaat ovat kuitenkin hyötyneet pienten palkkaerojen mallista. Kokonaisuudessaan vaikuttaa siltä, että $\mathrm{OECD-maiden} \mathrm{lisäänty-}$ nyt taloudellinen eriarvoisuus on hidastanut kasvua ja lisännyt työttömien määrää.

Palkkavetoisen talouden perusajatuksena on, että reaalipalkkojen nousu ja työn tuloosuuden kasvu nostavat myös investointiastet- 
ta ja tuotantokapasiteettia. Tasainen palkkajakauma on hyödyllinen, koska palkansaajat kuluttavat lähtökohtaisesti kaiken tienaamansa, eli heidän rajakulutusalttiutensa on suuri. $\mathrm{Ku}-$ lutus lisää kysyntää, ja se taas lisää tuotantoa ja investointeja. Palkkavetoisen talousajattelun näkökulmasta ei ole mitään takeita siitä, että yritysten investoinnit lisääntyisivät jos palkkoja lasketaan, kuten Suomessakin on moneen otteeseen vaadittu - käytännössä lähes nollasopimuksia on myös toteutettu. Työväen kannattaa kamppailla suurempien palkkojen puolesta, ja lopulta tämä hyödyttää kapitalistiakin, sillä investoiminen on turvallisempaa markkinoilla, joilla on pysyvää kuluttajakuntaa, kuin markkinoilla, joilla ihmisillä ei ole rahaa kulutukseen. Palkkojen kaksoisrooli on siksi otettava vakavasti: ne ovat tuotantokuluja yrityksille, mutta samalla myös kansantalouden perusta. Tätä ajatusta vastaan on argumentoinut muun muassa Valtion taloudellisen tutkimuskeskuksen johtaja Juhana Vartiainen, jonka mukaan ajatus palkankorotusten kasvua luovasta vaikutuksesta on "hölynpölyä."1 Vartiainen itse on vaatinut Osmo Soininvaaran kanssa Suomeen matalapalkkasektorin luomista. ${ }^{2}$

Alajan ja Suomisen mukaan Euroopassa ei tulisi tuijottaa ainoastaan julkisiin alijäämiin eli valtioiden velkaantumiseen. Sen sijaan tulisi kiinnittää huomiota yhtäältä kotitalouksien kestämättömään velkaantumiseen ja toisaalta euroalueen sisäisiin epätasapainoihin. Saksan talousmenestys on nimittäin perustunut nimenomaan matalapalkkasektorin luomiselle ja voimakkaasti vientivetoiselle taloudelle (vuonna 2012 51,6 \% Saksan BKT:sta muodostui viennistä). Saksan tulisikin nostaa palkkatasoa ja elvyttää tuotteiden kotimaista kysyntää. Tältä pohjalta Eurooppaan voitaisiin rakentaa järjestelmä, joka estäisi vaihtotaseiden liian suuret ali- ja ylijäämät. Sama pätee koko globaaliin talouteen. Erityisesti Kiinan vuosittainen huima yli 7 prosentin kasvu perustuu nimenomaan vientivetoiseen talouteen. Globaalin talouden tasapainottaminen vaatisi kuitenkin Kiinan sisämarkkinoiden lisäämistä, mikä joh- taisi luultavasti myös pienempään, mutta pitkällä aikavälillä vakaampaan kasvuun. Samalla myös Kiinan harrastama "työttömyyden vienti" vähentyisi, ja myös Euroopassa voitaisiin valmistaa eurooppalaisten tarvitsemia tuotteita. Palkkavetoinen talousmalli tuntuisi ruokkivan enemmän reaalitaloudellista toimintaa kuin finanssikapitalismia.

Kirjoittajat siis vaativat Euroopan laajuista käännettä kohti palkkavetoista talouspolitiikkaa, joka olisi heidän mukaansa reilumpaa myös työläisiä kohtaan. Lopulta voittojen taustalla on aina kuitenkin työläisten työ, ja siksi työn tuottavuuden ja yritysten voittojen kasvaessa myös työläisten tulisi saada "reilu osuus" tästä hyvästä. Pienemmät palkkaerot ja tasaisesti kasvavat palkat lisäävät investointeja ja tuovat vakautta talouteen. Vaatimuslistalla ei siis ole mitään varsinaisesti uutta - perinteiset hyvinvointivaltion ja vahvan AY-liikkeen menetelmät riittävät, kunhan ne toteutetaan tarpeeksi suuressa mittakaavassa.

2020-LUVUN JÄLKIKEYNESILÄISYYS?

Mutta kuinka on itse jälkikeynesiläisyyden laita? Suhtautuvatko kirjoittajat tarpeeksi kriittisesti esittelemäänsä talousteoriaan, ja ottavatko he huomioon kaikkia niitä taloudellisia ja yhteiskunnallisia, myös globaaleja valtapoliittisia asetelmia, jotka talouden toimintaan nykyisin vaikuttavat?

Mielestäni teoksen suurin ongelma on monipuolisen aikalaisanalyysin puuttuminen - joskaan se ei varmasti ole ollut tämän kirjan tavoitteena. Kirjoittajilla on selvä tavoite, mutta itse en ole täysin vakuuttunut siitä, että se olisi saavutettavissa näin helposti ja että esitetyt keinot tämän päämäärän tavoitteluun olisivat täysin riittävät. Näin tuskin ajattelevat kirjoittajatkaan, mutta esitän tästä huolimatta muutamia kriittisiä kysymyksiä, joista olisi syytä keskustella edelleen niin jälkikeynesiläisten talousteorian kuin sosiaalidemokraattisen politiikankin yhteydessä. 
Kirjassa puhutaan paljon talouden ongelmista, mutta itse sosiaalidemokratian kriisiä ei kuitenkaan juuri mainita. Lukijalle voikin jäädä sellainen vaikutelma, että jälkikeynesiläisten talousoppien perustalle rakennettu täystyöllisyys palauttaisi uskon ja luottamuksen sosiaalidemokratiaan yleisemminkin.

Nähdäkseni sosiaalidemokratian kriisi ei kuitenkaan johdu ainoastaan työttömyydestä vaan myös yleisemmästä paradigman vaihdoksesta Euroopassa. Kyseessä on toki työ ja toimeentulo, mutta myös arvot ja kulttuuri. Sosiaalidemokraattinen politiikka on tehnyt monia vakavia arviointivirheitä viimeisen 25 vuoden aikana, eikä ole liioiteltua sanoa, että juuri sosiaalidemokratia on ollut itse ajamassa uusliberalistisia käytänteitä niin Suomessa kuin muissakin Euroopan maissa. Saksan malli on hyvä esimerkki "työtä hinnalla millä hyvänsä" -politiikasta. Siksi sosiaalidemokraattisen ajattelun tulisi tarkistaa lähtökohtiaan monipuolisesti ja ottaa myös suuri kysymys "työpaikka vai työläinen" vakavasti käsittelyyn. Nykyisin pääasiassa keskiluokan hyvinvoinnin ja työllisyyden nimiin vannovan sosiaalidemokratian olisikin syytä taas miettiä myös köyhiä työläisiä ja työttömiä potentiaalisena äänestäjäkuntanaan ja harjoittaa sen mukaista politiikkaa. On epätodennäköistä, että kasvava matalapalkkaaloilla työskentelevä työläisjoukko haluaisi äänestää hyvin toimeentulevan keskiluokan arvojen ja näkemysten mukaisesti.

Toinen tähän läheisesti liittyvä kysymys koskee tuotantorakennetta. Tarkoittaisiko jälkikeynesiläinen täystyöllisyyspolitiikka jonkinlaista paluuta tehdastuotantoon ja massatyöläisten hegemoniaan? Toisin sanoen, miten todella työllistää Suomen 300000 ja Euroopan 25 miljoonaa työtöntä työnhakijaa? Rakennammeko lisää ydinvoimaloita ja aloitammeko uudelleen esimerkiksi vaateteollisuuden? Ja mitä tällainen toiminta tarkoittaisi maailmantaloudessa - onko se ylipäätään mahdollista? Jos taas seuraamme nykyistä eurooppalaista linjaa eli vähän työllistävän korkeasti palkatun tietotyön ja huonosti palkatun palvelutyön kombinaatiota, tarvitaan todellisia innovaatioita luomaan riittävästi uutta työtä. Mielestäni kirjassa kiinnitetäänkin aivan liian vähän, jos ollenkaan, huomiota tuotantorakenteen muutokseen. Sama koskee kenties myös kapitalistisen kasautumisen logiikkaa ja siihen liittyvää globaalia poliittista agendaa.

Tarkoitukseni ei kuitenkaan ole sanoa, ettei täystyöllisyys olisi tavoittelemisen arvoista. Olisi kuitenkin syytä miettiä, mitä täystyöllisyys voisi nykyään tarkoittaa. Sosialidemokraattiselle puolueelle ja AY-liikkeelle esimerkiksi perustulo on ollut jos ei nyt punainen vaate, niin vähintäänkin kelvoton yhteiskunnallinen uudistusehdotus. Tämänkin kirjan lopussa sivutaan hyvin lyhyesti kysymystä perustulosta, mutta asiaan ei varsinaisesti oteta kantaa. Rivien välistä tosin voi helposti lukea, että esimerkiksi Osmo Soininvaaran esittämää perustulomallia pidetään työvoiman tarjontapuolen ratkaisuna - siis uusklassiseen paradigmaan kuuluvana ehdotuksena.

Sosiaalidemokraatit ja AY-liike voisivat kuitenkin nähdä perustulon myös eräänlaisena täystyöllisyyteen johtavana investointina, jolla päästäisiin ensiksikin eroon työttömyyden kategoriasta ja toiseksi mahdollistettaisiin uudenlainen mikrotaloudellinen toiminta. Jos - ja oman ymmärrykseni pohjalta kun - teollisuustyöpaikkojen massamittainen lisääminen Suomessa on nostalginen päiväuni, olisi syytä miettiä millaista työvoimavaltaista tuotantoa meillä voitaisiin tehdä tulevaisuudessa? Ensimmäisinä mieleen tulevat erilaiset palvelut, luovat alat, hoitoala sekä toisaalta esimerkiksi vaihtoehtoisen maatalouden mahdollisuudet.

Kysymys onkin paljolti siitä, perustuuko kansantalous yhden tai kahden suuren sektorin tuotantoon vai koostuuko kansantalouden hyvinvointi pikemminkin monipuolisesta tuotantorakenteesta. Perustulo voitaisiinkin siksi nähdä eräänlaisena pitkän tähtäimen jälkikeynesiläisenä ratkaisuna ja investointina, jonka tarkoituksena olisi uudistaa ja monipuolistaa tuotantorakennetta seuraavan 25 vuoden aikana. Tämä ei tarkoita teollisuudesta luopumista, 
mutta se voisi tarkoittaa aivan uudenlaisten tuotannon ja työn muotojen kannustamista valtion taholta. Lyhyesti sanottuna, perustulosta olisi keskusteltava juuri tuotantopuolen kysymyksenä, ei vain sosiaaliturvan uudistamisena, jolloin siitä väistämättä uhkaa tulla uusliberalistinen hyvinvointivaltion palveluita rapauttava ja ihmisiä köyhdyttävä muutos.

Kolmantena suurena kysymyksenä nousee esiin ekologinen ulottuvuus. Tällä hetkellä oikeastaan kaikessa lukemassani jälkikeynesiläisessä keskustelussa muistetaan kyllä mainita ekologiset ratkaisut, mutta mitään sisällöllistä näistä mahdollisuuksista ei sanota. Jos tavoitteena on globaali täystyöllisyys - kuten jotkut ovat ehdottaneet - tarkoittaa se nykyisellä tuotantomallilla maapallon ekosfäärin nopeaa tuhoutumista. Valitettavasti suuri osa nykyisestä taloudellisesta toiminnasta ja tuotannosta on maapallon kannalta haitallista. Ihmisetkään eivät tarvitse kaikkea sitä, mitä markkinatalous tuottaa. Siksi täystyöllisyyden tavoitteesta puhuttaessa on puhuttava sisällöllisesti ekologisesta työstä,joka perustuu kierrätykseen sekä energiankulutuksen ja talouskasvun vähentämiseen. Tämä kuulostaa paradoksaaliselta, mutta nähdäkseni pelkkä ihmiskasvoinen kapitalismi ei riitä ilmastonmuutoksen ja muiden ekologisten katastrofien hidastamiseen.

Sen sijaan tarvittaisiin ekologista sosialismia, jossa sosialismilla tarkoitan pääasiassa tuotannon suunnittelua ja ohjaamista luonnonmukaiseen suuntaan. Valtioiden tai esimerkiksi Euroopan unionin olisi siis selkeästi päätettävä, mitkä tuotteet ja tuotantomuodot ovat niin haitallisia ja ekologisesti kestämättömiä, että niitä ei voida enää käyttää. Käytännössä tämä tarkoittaisi työvoimavaltaisen paikallistalouden vahvistamista niin ruuantuotannossa kuin esimerkiksi vaateteollisuudessa. Itse uskon, että keynesiläisellä suurella valtiolla ja isolla pankilla voisi olla tarjotta- vaa nimenomaan tämänkaltaiseen radikaaliin muutokseen. Samalla tulisi puhua myös työn jakamisesta ja palkkatyölle ulkoisen työn merkityksen lisäämisestä. Siksi jälkikeynesiläisessä keskustelussa olisi hyvä kiinnittää huomiota myös muihin kuin palkkatyövälitteisiin hyvinvoinnin tuotannon muotoihin.

Lopputulemana kirjoittajat esittävät, että kapitalismi tulisi jälleen taltuttaa laajempien kansanryhmien palvelukseen. Nähdäkseni tämä on hyvä tavoite, ja kirja tarjoaa monia ehdotuksia, joilla tätä tavoitetta voidaan lähestyä. Tästä huolimatta jälkikeynesiläisen talouspolitiikan tavoiteasteikkoa voisi kiristää hieman radikaalimpaan suuntaan. Jos suuria makrotaloudellisia muutoksia todella aletaan tehdä esimerkiksi Euroopan keskuspankin tasolla, tulisi mielestäni myös poliittisen suunnanmuutoksen olla selvempi. Työtä ja hyvinvointia tahtovat kaikki, mutta tämän lisäksi olisi kysyttävä, onko niitä mahdollista tavoitella ekologisesti ja kestävästi, vallitsevan fossiilikapitalismin erittäin negatiivisia rakenteita purkaen. Ja kuinka tämä voitaisiin tehdä ilman vakavia kansainvälisiä konflikteja? 2000-luvun haasteet ovat toisenlaisia kuin 1900-luvun kysymykset. Siksi keynesiläisyyttä on päivitettävä edelleen, säilyttäen samalla sen talouspoliittisesti radikaalit tavoitteet ja pitäen kiinni sen pyrkimyksestä sosiaaliseen tasaarvoon. Nähdäkseni Alajan ja Suomisen teos on tärkeä askel tähän suuntaan.

\section{— MIKKO JAKONEN}

\section{VIITTEET}

1. Sayn laki -juhlaseminaari 210 vuotta, 20.11.2013, Helsingin yliopisto.

2. Soininvaara \& Vartiainen 2013. "Lisää matalapalkkatyötä” teoksessa Matalapalkkatyö Suomessa. Valtioneuvoston kanslian raporttisarja 1/2013, s. 31-62. 